\title{
Implication of Web 2.0 in E-Government
}

\author{
${ }^{1}$ Gajendra Sharma, ${ }^{2}$ Subarna Shakya and ${ }^{3}$ Rajendra Man Banepali \\ School of Engineering, Department of Computer Science and Engineering, Kathmandu University \\ Dhulikhel, Kavre, Nepal \\ ${ }^{2}$ Department of Electronics \& Computer Engineering, Institute of Engineering, Tribhuvan University, Nepal \\ ${ }^{3}$ SinghaniaUniversity, Rajasthan, India
}

\begin{abstract}
In recent years, a number of governments have worked to increase openness and transparency in their actions. Information and communication technologies (ICTs) are considered as a cost-effective and convenient means to promote openness and transparency for public interaction. Web 2.0 or social media tools are increasing the level of participation of all stakeholders in the process of creating, maintaining, sourcing, and sharing information. Emerging interactions between the people and government itself are creating opportunities for increased accountability, transparency, participation, and collaboration. A well-planned e-government strategy can establish a more efficient, accountable and transparent government. This review paper highlights the use of web 2.0 in e-government and concept of e-participation, discusses e-government challenging issues and provides significance of e-government for policy makers. E-government has been proposed as a way to increase public trust in government and enhance citizen evaluations of government. Public attitudes and eparticipation toward government are central part for democratic governance and public administration.
\end{abstract}

Keywords: Web 2.0, Social Media, Social Network, E-Government, E-Participation, Policy, Public Administration

\section{Introduction}

E-government is the delivery of government services and information every time. The e-Government policy focus is concerned with efficiency and effectiveness. The future move of e-government includes governance issues, along with efficiency and effectiveness, such as promoting economic growth, jobs, competitiveness and sustainable development[28]. It further includes democracy, quality of life, citizenship, trust, stability, and universal human rights. The policy goals of government and e-Government distinguish the public sector from the private sector, given that the latter generally observes the constituent as a consumer. ICTs offer new means for openness by providing access to Web 2.0 or social media, content and interactions that are created through the social interaction of users through highly accessibly web-based technologies. Web $2.0 \mathrm{can}$ be used to refer to both the enabling tools and technology and to the content that is generated by them. It includes blogs, wikis, social networking sites such as Facebook, Myspace, micro-blogging services (e.g. Twitter), and multimedia sharing services (e.g. Flickr, YouTube). The popularity of LinkedIn supports that social media such as blogs are used for professional purposes, as the primary use of LinkedIn is for job hunting and recruitment, according to the site's own profile and user instructions.

Internet social networking tools and Web 2.0 technologies are providing a new way for web users in information sharing and knowledge transformation [35]. The internet social networking tools have been utilized as a solution in emergency response during disasters. Web 2.0 platforms, mobile communication technologies and social networking could change interactions between government and people for positive benefit. An internet- based emergency response system would have allowed people to use mobile telecommunications devices to report events to the government to facilitate search and rescue. By using telecommunications technology such as Web 2.0, microblogging and other social network technologies governments could transform infrastructure to assist individual and communities respond to and recover from disasters [20]. As regards Web 2.0 technology in use, e-government will focus on transparency of its services to provide activities of the 
administration visible and support cooperation, adaptive and service-oriented information architectures in integration with existing systems and services. Moreover, E-government services are focused mainly on the individual citizen it will pursue public problems in terms of advanced visualization techniques for decision making processes.

The purpose of this paper is to emphasize the use of web 2.0 in e-government, concept of e-participation as well as challenging issues and significance of e-government for policy makers. The term Web 2.0 is widely attributed to Tim O'Reilly who used it to a second generation of web-based services that feature openness for collaboration and interactivity [4]. Web 2.0 or social media tools can exchange information with the people and exploit the collective initiative of the public to support the mission. Social media can assist on cost savings, its strength lies in increasing public engagement which helps a government agency to accomplish its goal.

\section{E-Participation Concept}

The rapid development of ICT brings new challenges to business and public sector. From the point of view of public sector ICT have been challenging in several perspectives. The public opinion is available through published view through easily accessible online papers, newsgroups, and blogs or Web 2.0 social media tools. These issues raise a need for higher quality e-government services and active interaction between government and citizens [21]. On the other hand, the support of administrative processes as well as electronic democracy was envisaged [7]. An adequate attention was paid how ICT transform public administration processes in order to make them more efficient [16] and the awareness is given to e-participation field. In this connection, eparticipation can be defined as adopting ICT within politics in regard of participatory, self organized democracy and grassroots communication and discussion processes. In general, e-participation represents that technologies, resources, organizations, and skills enable humans to design and manage their social systems all by themselves and to develop collective visions of a better future so that collective intelligence can materialize. Nevertheless, the human abilities and ways of employing such technologies for political communication has to be taken into consideration as well [30]. As Millard (2008) [27]observes such e-participation is moved by various ICT means "from the more traditional emails and electronic forums, to the Web 2.0 phenomenon of social networking, and applications which enable users to upload their own content and manipulate the content of others, as well as facilitate deliberation and debate".

E- Government is adopted with the purpose of improving the services and delivery provided by the government to its citizens. User acceptance of technology is a key driver determining the rate of change. ICT enables both users and employees of the organization to be more effective and productive in receiving, providing and delivering electronic services. ICT does not only allow the formation of virtual or online teams for working closely together irrespective of geographical boundaries but also has the potential to outreach the people around the world. Warkentin et al. [31] define adoption as the intention of people to involve in egovernment to collect information and request services from the government. Carter and Belanger [32] measure it as intent to implement and intention to use e-government services. Effective e- government has the ability to generate new methods and avenues for participation in government, electronically threading together people, businesses, and all levels of government in a country. The successful adoption of e-government services is important for governments. Akman et al. [33] explained that the success of e-government adoption depends on public efficiency. E-government services offer public precision in the process of governance, such as prompt and efficient services, simplification of procedures, and friendly attitudes of an individual.

Macintosh (2004) [24]provided definition of e-participation as the use of ICTs to support information stipulation, top-down engagement which is concerned with support for government-led initiatives, and groundup empowerment which is largely connected with the support to enable citizens, civil society organizations and other democratically constituted group to engage with their elected representatives and officials. Within overall framework of applying ICT in public organization e-participation comprise to political value establishment. As noted by Millard (2008),[27]ICT provide value for public organizations in three ways: political democracy value, organizational value and customer value through effective services. From the perspective of political democracy value e-participation is treated as openness and participation increasing tool enchasing public trust through open, transparent, accountable, flexible and participatory administration and policy making. 
The usability of the applications, tools, channels and devices through which e-participation will take place in virtual space, need to be designed properly to support the people in this regard [13].E-government has been proposed as a way to increase public trust in government and enhance citizen evaluations of government. There is a significant relationship between trust and use of a local government web site, as well as other positive assessments of federal and local governments. The evidence suggests that e-government can increase eparticipation by improving interactions with citizens and perceptions of responsiveness [29]. Public attitudes and e-participation toward government, including trust, are central part for democratic governance and public administration. As reported by European Commission (2008), [11] a number of people today are losing interest and confidence in the way their countries are being governed. Issues of openness, trust, and transparency are being repeatedly and immensely discussed as the public manifests lack of confidence in public servants and governmental institutions [26].

\section{Opportunities and Challenges}

The combination of e-government, Web 2.0 or social media, web-enabled technologies, mobile technologies, transparency policy initiatives, and public desire for open and transparent government are delivering a new age of opportunity that has the potential to create open, transparent, efficient, effective, and user-centered ICT-enabled services. An extensive range of nations with varying technology infrastructure have created several procurement, tracking, anti-corruption, and other systems that assisted national and state governments engagement in transparent government activities. Moreover, the systems opened government to public inspection, thereby reducing corruption. Before attempting to understand what Web 2.0 provides for edemocracy, it needs to understand wider implications for political behavior that stays close to its technological characteristics. O'Reilly's technology-centered approach defines Web 2.0 in terms of seven key themes [5].The seven principles are: the Internet as a platform for political discourse; the collective intelligence emergent from political web use; the importance of data over particular software and hardware applications; perpetual experimentalism in the public domain; the creation of small scale forms of political engagement through consumerism; the propagation of political content over multiple applications; and rich user experiences on political websites. This principle indicates that the web has moved from the older model of static pages toward a means of enabling a wide range of goals to be achieved through networked software services.

Easily scalable networking involves an organization being able to flexibly adapt to sudden growth surges and ad hoc events that increase demand for its services. The Internet contributes to a varied and pluralistic media background. The web-as-platform principles can be seen at work in a range of political arenas [19]. The idea more strongly embodied in the recent shift towards online social networking on platforms such as Facebook and MySpace, and social media sites such as YouTube. Digital access and capabilities in dealing with ICT have been identified as relevant for personal fulfillment and development, active citizenship, social inclusion and employment. Moreover, avoiding the emergence of new inequalities, digital inclusion contributes to social inclusion to the extent that people at risk of exclusion can be empowered through ICT. Web 2.0 may support the enhancement of public social capital as it facilitates interactions between offline and online community and the improvement of social relations by creating and maintaining links through the use of social networks. In addition, Web 2.0 can also contribute to the development of cultural capital of disadvantaged people as it broadens the access to digital content and other opportunities which facilitate learning processes [1]. Social media can create new digital divides widening the gap created by digital and social exclusion for already helpless groups and people. At the same time it can also be an enabler of self-organization [14]and self-help processes started by, or involving, socially-excluded people that transform weak ties created across the online and offline worlds into effective collective structures of engagement and participation.

Social media function to realize user and society driven innovation instead of technology driven innovation. However, despite the success of new e-government services, significant analysis is necessary to assess whether social media have prospective to bridge the gap between digital and social inclusion[19]. On the other hand, possible negative aspects related to social media and Web 2.0 may not be neglected. The greatest barriers to the adoption of e-government, in order of frequency of response, were: lack of technology or web staff; lack of financial resources; lack of technology or web expertise; issues regarding security; and the need to upgrade 
existing IT [15]. There should be little wonder that local governments have moved ahead slowly in the further and more sophisticated development of their e-government presence. Some important factors relating to this are presented below:

Technology literacy: The ability to understand and use technologies

Usability: The design of technologies that are sensitive and allow users to engage in the content embedded within the technology

Accessibility: The ability of persons with disabilities to be able to access the content through adaptive technologies

Functionality: The design of the technologies to include features such as search, e-government service tracking and accountability measures that users desire. Therefore, it is essential to both use technologies that are widely deployed to provide a wide base of technology access, but there is also often a considerable need to provide training, and engage in usability, functionality, and accessibility testing to ensure the broadest ability to participate in e-government services and resources. The use of social media as a core part of transparency initiatives also can create both new opportunities and challenges.

The expansion of e-Government web sites and the online sharing and posting of information have changed ways of communication. Users should understand their responsibilities for conducting themselves online. An important component for this is cyber ethics. Cyber ethics refers to the code of responsible behavior of the users on the internet. The basic tenets of cyber ethics should be employed to be good cyber citizens [17]. In most cases, the greatest limitations to e-Government are non-technical, in the management category, such as political opposition, deeply ingrained policies and practices, and internal employee resistance. While E-Government is subject to the same threats as e-business, e-Government operates within different constraints. Most businesses deal only with a subset of the population, and they can choose the how and the when they do it. But the government must deal with everyone [9].Therefore, because of the huge number of users and transactions, and sensitivity of this field, like citizen's private information or government's secret information, and other issues, securing governmental networks considered of high importance.

\section{Trust in E-Government}

Scholars have conceptualized trust as a product of public preferences regarding results of policy or electoral outcomes. But preferences and outcomes explain only one part of the dissatisfaction with government. Previous surveys show individuals with low trust in government say that policies do not reflect their beliefs and values. Recent study provides evidence that citizens base their evaluations on process considerations about how fair, open, and responsive political and governmental processes are [10,2]. Citizen trust about the fairness and responsiveness of government processes are vital. Two modes for the creation of trust that are significant for egovernment are found: process-based trust and institutional-based trust. Process-based trust is rooted in repeated interactions with government. As a result of these interactions, individuals participate in instrumental exchanges and get what they need, but there are also symbolic exchanges. One dimension of trust is based on perceptions that government cares about people, their needs, and expectations i.e., perceptions that government is responsive. Institutional-based trust is an opinion of institutions rather interactions and it conveys an expectation that institutions will do what is right. Citizens trust institutional expertise or past institutional practice. In several ways, institutional-based trust represents an image held by respondents. Institutional actions that conform to public expectations may boost an institution's reputation.

There is extensive concern that the citizen has lost faith in the performance of the core institutions of representative government, and it is estimated that more open and transparent government and efficient service delivery could help restore that trust. E-government, which has been proposed as one solution, "refers to the delivery of government information and services online via the Internet or other digital means" [4]and may include opportunities for online political participation [29]. E-government holds promise for enhanced delivery of public services, including online transactions, and for transforming information about the function of government. It can improve communication between citizens and government through e-mail, enabling direct participation in government decision making. An early study of e-governance conducted by the Organization for 
Economic Co-operation and Development (OECD), based on interviews with information specialists, public officials, and the policy-making community in eight postindustrial countries found that the "overall impact of the Internet had failed to increase access to policymakers, to improve the transparency of government decision making, or to facilitate public participation in policy making" [2]. Some survey data suggest that public attitudes are affected by e-government $[8,34]$. West (2004) [47] analyzes national survey data [8]and finds that exposure to information about e-government is significantly related to the opinion that government is effective at solving problems, but it is not related to trust in government.

\section{Implication of Web 2.0 in E-Government}

Web 2.0 or social media tools are increasing the level of participation of all stakeholders in the process of creating, maintaining, sourcing, and sharing information [9]. Emerging interactions between the public and government itself are creating opportunities for increased accountability, transparency, participation, and collaboration. Furthermore, social media tools are potentially disruptive and have transformative effects on information sharing that have not been fully covered in the public administration literature [26].In the public sector, several new types of information production and sharing tools are emerging in form of grassroots developments called social media, Web 2.0 tools, or the social web. These are tools that are used in digital environments in which contributions and interactions among all stakeholders are enabling a high degree of collaborative knowledge creation and sharing $[4,34]$. These are web applications that emerged in private settings outside any business or government context. They are rapidly making their way into the public sector [33].

The social media phenomenon has established a need for novel research approaches in public administration to understand the underutilized resources of emergent interactions and voluntary contributions in which citizens and public sector employees are engaging. Social science itself is lagging behind in collecting and analyzing large scale behavioral data, such as information created on political blogs or the content and contacts created on social networking sites (e.g., government Facebook groups). New forms of study, such as social network analysis, can assist to explain these informal dynamic structures and their content $[5,17]$. In the past few years, e-government has been a topic of much interest about the advent of Web 2.0 technologies. Government use of technology and the Internet must and will continue to increase in the wake of their citizens' technological adoption, yet there are still many questions and concerns about the progress and future of e-government.

An analysis of participation in the first generation of e-government initiatives worldwide provided limited usage of e-government services. Increased use of Web 2.0 was suggested as the solution to low participation, leading to a generation of broader, deeper, and more advanced e-participation [6]. Some organizations discovered the problems inbuilt in utilizing mainstream of social media services. For example, trust becomes an issue when ads on a government Facebook page undermine to the message or goal of the page. Also, privacy on Facebook has been a problem for years. People may not know the difference between the social media source and the government agency using it [19]. Additional concerns include accessibility to the disabled, which does not appear to be a priority to Web 2.0users, and the limitations of the format and design can prevent government agencies from reaching particular groups of citizens. Social media can enable internal communication and collaboration, exchange information with the public, and keep speed with fast moving events in real time. Social media will become more popular, more mobile, and more exclusive. As pointed out by Armano (2009) [3], with approximately 70 percent of organizations banning social networks, accessing social networks through mobile devices will increase.

\section{E- Government Measurement for Policy Makers}

The e-government policy focus has moved from being concerned with efficiency to being concerned both with efficiency and effectiveness. From an almost exclusive focus on the efficiency impacts of e-government over government itself, there is a clear movement towards an increased attention on effectiveness impacts, as well as to wider governance impacts. This is going hand-in-hand with a change away from measuring only the inputs and outputs of e-government initiatives towards a much greater emphasis on analyzing and measuring the outcomes for constituents and the impacts on society as a whole, for example through increased public value. 


\subsection{Measurement and the Evolution of E-Government Policy}

A number of sources point to three major policy goals of government and e-government, each with a distinctive view of who the constituent is and who benefits from the policy. Each of these policy goals assume a different relationship between government and constituents, and need to deal with their own policy contradictions[27]:

- Efficiency and the search for savings: benefits for government: a dynamic, productivity-driven, innovative and value for money set of institutions, where the constituent is seen as a tax-payer and the policy dilemma is how to provide 'more for less'.

- Effectiveness: the search for quality services: benefits for the constituents: producing and delivering interactive, user-centered, innovative, personalisable, inclusive services, maximizing fulfillment and security, where the constituent is seen as a consumer, but where services are provided to all on the basis of need instead of demandthe policy dilemma is how to pursue both need and demand and how to balance the two.

- Governance: the search for good governance: benefits for society: open, transparent, accountable, flexible, participatory, democratic, etc., where the constituent is seen as a citizen, voter and participant there are two policy dilemmas, how to balance openness with legitimate privacy and how to balance the ultimately irreconcilable interests of society's different stakeholders.

The policy goals of government and e-government distinguish the public sector from the private sector, provided that the latter generally observes the constituent as a consumer [28]. Accompanying this evolution of policy goals there is a simultaneous development in the way they are operationalised and measured. This has also involved a greater realization that it is important to be explicit about why measurement in the information society in general, and e-government in particular, is being undertaken [18].

\subsection{Policy Measurement}

Within the broader information society domain, both Heeks (2006) [18] and Millard \& Shahin (2006) [28]have constructed an e-government analytical framework and evaluation system using a policy impact assessment. They adopt a holistic approach which links e-government into the overall policy development process, but also allows operationalisation and measurement to take place at one or more levels as long as their place in the whole policy framework is appreciated. Being precise about pursued objectives and measures also allows policy-makers to verify that the proposed logic of involvement is reasonably strong. Moreover, this is also a way to promote a common understanding of the aims of the policy, which is also necessary when it is adopted, monitored and measured through specified indicators in order to evaluate its success.

\section{3 Major E-Government Policy Measurement Trends}

There are two major trends in policy making and policy measurement in e-government, both of which are expected to become more important in the future.

\section{Up the Policy Value Chain}

There is increasing focus on making and measuring policies higher up the policy value chain. This implies a movement from efficiency to effectiveness to governance. This does not necessarily mean than the first is being discarded, rather that all three policy goals are being linked and measured more explicitly together as one system. In essence, this is synonymous with a move up the e-government policy objective and evaluation levels. Again this does not necessarily mean that the lower levels are being discarded, but rather that the higher levels are being included for the first time. The European Commission started for the first time to take initial steps to articulate and measure the broader policy impacts of e-government on competitiveness, growth and jobs [12].

\section{From Centre to Local and Down the Hierarchy}

There is a trend which is not yet widely established but is now being seriously discussed and pointed out in some parts of the public sector. This is to move both policy target setting and measurement from central government to local government and from the back-office to the front-office to front-line staff, whether care or medical professionals, police, community workers, teachers and to constituents themselves such as citizens, families, communities, localities, businesses and their related organizations. This type of policy target setting and measurement is using, for example, staff and user panels to design standards and outcomes, such as person- 
centric measures of success in education, health and social care, to complement the top-down and macro measures of targets and standards provided by central government [23].

\section{Conclusion}

E-government has attracted attention as one way of improving citizen interactions with government. Social media such as Web 2.0 and social networks is widespread among public relations practitioners and scholars. While providing additional convenience for citizens to access governmental information and services, egovernment must be implemented cautiously. Implementing e-government is a continuing process, and most often the development is conceptualized in stages. The task of e-participation is to empower people to be able through ICT to act in bottom-up e-government decision making processes, thus allowing politicians to make informed decisions, while developing social and political responsibility. The use of Web 2.0 or social media in e-government differs by social culture and form of government. The challenges that need to be addressed in egovernment include suitable ICT support in foresights and policy modeling, especially in the long-term policy planning, capability of managing complexities in strategic planning and policy making in complex socioeconomic environments. Government should either adapt the existing web accessibility guidelines or develop its own guidelines that are appropriate for their context. There has been conducted limited empirical research on egovernment's influence on citizen attitudes. Future study on social media in e-government is needed in the areas of public attitudes, categorization of e-government applications, and policy-making.

\section{References}

[1] K. Ala-Mutka, D. Broster, R. Cachia, C.Centeno, H.Feijóo, S.Kluzer, S., Lindmark, W. Lusoli, G. Misuraca, C.Pascu, Y.Punie, andJ.A. Valverde,The Impact of Social Computing on the EU Information Society and Economy, Luxembourg: Office for Official Publication of the European Communities, 2009.

[2] C. Anderson, B. Andre, B. Shaun, D. Todd and L. Ola ,Loser's Consent: Elections and Democratic Legitimacy. Oxford : Oxford University Press, 2005.

http://dx.doi.org/10.1093/0199276382.001.0001

[3] D. Armano,“ Six Social Media Trends for 2010”,Harvard Business Review, 2010.http://blogs.hbr.org/cs/2009/11/six_social_media_trends.html (Accessed on November 2, 2010).

[4] M. Boler(Ed.),Digital Media and Democracy: Tactics in hard times, Cambridge, MA: MIT Press, 2008.

[5] S.P Borgatti,.A. Mehra, D. Brass and G. Labianca, Network Analysis in the Social Sciences, Science, Vol. 323,pp. 892- 895,2009.

http://dx.doi.org/10.1126/science.1165821

[6] Y. Charalabis and E. Loukis, Transforming Government Agencies' Approach to E-Participation through Efficient Exploitation of Social Media, In Proceedings of the 2011 European Conference on Information Systems, pp. 1-12, Helsinki, Finland, 9-11 June 2011.

[7] S. E Colesca, Understanding Trust in E-Government, Inzinerine Ekonomika-Engineering Economics, Vol. 3, pp. 7-1, Communication from the commission to the council, the European parliament, the European economic and social committee and the committee of the regions: Putting knowledge into practice: A broad-based innovation strategy for the EU, Brussels, 2009.

[8] Council for Excellence in Government, The New E-Government Equation: Ease, Engagement, Privacy and Protection, www.excelgov.org/admin/FormManager/fi lesuploading/egovpoll2003.pdf . 2003 (Accessed on January 30, 2006).

[9] S.S. Dawes, M. Anthony, M. Cresswell, and A.P. Theresa,"From "need to know" to "need to share": tangled problems, information boundaries, and the building of public sector knowledge networks", Public Administration Review, Vol.69, pp. 392- 402, 2009.

http://dx.doi.org/10.1111/j.1540-6210.2009.01987_2.x

[10] D.Todd, and S. Bowler, Reforming the Republic: Democratic Institutions for the New America, Upper Saddle River, NJ : Pearson/Prentice Hall, 2004.

[11] European Commission, Joint Research Centre, Institute for Prospective Technological Studies: Seville, Spain, 2008, Available online: ftp://ftp.jrc.es/pub/EURdoc/EURdoc/JRC45269.pdf (Accessed on 20 November 2011). 
[12] European Commission, The Impact of E-Government on Competitiveness, Growth and Jobs, IDABC E-Government Observatory, Background Research Paper, February 2005.

[13] C. Fraser, L., Naoum, B. Lippa, M. Mach, A. Macintosh, M.Marzano, M. Flavia, R. Gregoris. DEMO_net Deliverable 5.1: Report on current ICTs to enable Participation.,Deliverable, Vol. 4, 2006.

[14] C. Fuchs,Internet and Society, Social Theory in the Information Age, New York/London: Routledge, 2008.

[15] S. Gajendra S., B. Xi and Q. Wang,"E-Governance: Public Participation and Ethical Issues", Journal of E-governance, Vol..35, pp. 195-204, 2012.

[16] R. Gatautis, "The Impact of ICT on Public and Private Sectors in Lithuania", Inzinerine Ekonomika-Engineering Economics, Vol. 4, pp. 18-28, 2008.

[17] R.K. Gibson, "New Media and the Revitalisation of Politics”,Representation Vol. 45, pp. 289-299, 2008. http://dx.doi.org/10.1080/00344890903129566

[18] R. Heeks, Understanding and Measuring E-Government: International Benchmarking Studies, Paper prepared for UNDESA workshop, "E-Participation and E-Government: Understanding the Present and Creating the Future", Budapest, Hungary, 27-28 July 2006.

[19] R. Hellman, The Cloverleaves Of Social Media Challenges for E-Governments, In proceedings of e-challenges e-2011 conference, pp. 1-8, Florence, Italy, 26-28 October 2011.

[20] C.M. Huang, E. Chan and A.A. Hyder,"Web 2.0 and Internet Social Networking: A New Tool for Disaster Management"? - Lessons from Taiwan,Medical Informatics and Decision Making, Vol.10, p. 57, 2010. http://dx.doi.org/10.1186/1472-6947-10-57

[21] L. KasubieneandP. Vanagas, "Assumptions of e-Government Services Quality Evaluation”,Inzinerine EkonomikaEngineering Economics, Vol.5, pp. 68-74, 2007.

[22] D. Lazer, A.Pentland, L.Adamic, S. Aral, A. L.B., D. Brewer, N. Christakis, N. Contractor, J. Fowler, M.Gutmann, M. Ines, D.Lazer, and M. C.Binz- Scharf,"Lending a Helping Hand: Voluntary Engagement in Knowledge Sharing",International Journal of Learning and Change, Vol.3, pp. 5- 22, 2008.

[23] C. Leadbeater and H. Cottam,TheUser Generated State: Public Services 2.0, 2008.http://www.charlesleadbeater.net/archive/public-services-20.aspx (Accessed 7 March 2008).

[24] A. Macintosh, Characterizing E-Participation in Policy Making, HICSS, Proceedings of the 37th Annual Hawaii International Conference on System Sciences (HICSS 2004).

[25] M. Ines, D.Lazer, and M. Christina Binz- Scharf., "Lending a Helping Hand: Voluntary Engagement in Knowledge Sharing",International Journal of Learning and Change, Vol.3, pp. 5- 22, 2008.

http://dx.doi.org/10.1504/IJLC.2008.018865

[26] J. Millard, M.M. Nielsen, S. Smith, A. Macintosh, E. Dalakiouridouand E. Tambouris, D5.1a: E-participation Recommendations - First Version, European e-Participation Consortium, 2008.

[27] J. Millard,E-Government Measurement for Policy Makers, European Journal of E-Practice,www.epracticejournal.eu, Vol. 1, pp. 1-14, 2008.

[28] J. Millard and J. Shahin, Study for the Impact Analysis of FP5 E-Government Projects, Under the WINGframework contract for impact analysis for the European commission, DG INFSO, April 2007.

[29] K. Mossberger, C. Tolbert, and M. Stansbury, Virtual Inequality: Beyond the Digital Divide, Washington, DC: Georgetown University Press, 2003.

[30] B. Neverauskas, andR. Tijunaitiene, "Public Participation in City Governance Decision-Making: TheoreticalApproach, InzinerineEkonomika-Engineering Economics, Vol.4, pp. 27-35, 2007.

[31] M. Warkentin, D. Gefen, P.A. Pavlou, and G.M. Rose, "Encouraging Citizen Adoption of E- Government by Building Trust", Electronic Markets, Vol. 12, pp. 157- 162, 2002.

http://dx.doi.org/10.1080/101967802320245929

[32] L. Carter and F. Belange, "The Utilization of E -Government Services: Citizen Trust, Innovation and Acceptance Factors, Information Systems Journal, Vol. 15,pp. 5- 25,2005.

http://dx.doi.org/10.1111/j.1365-2575.2005.00183.x

[33] I. Akman, A. Yazici, A. Mishra and A. Arifoglu, "E-Government: a Global View and an Empirical Evaluation of Some Attributes of Citizens", Government In formation Quarterly, Vol. 22, pp. 239- 257, 2005. 
2015 International Conference on Data Mining, Electronics and Information Technology (DMEIT'15) August 10-11, 2015 Pattaya, Thailand

http://dx.doi.org/10.1016/j.giq.2004.12.001

[34] D.M. West, Assessing E-Government: The Internet, Democracy, and Service Delivery by Stateand Federal Governments, Washington, DC : World Bank, 2000. 